NBER WORKING PAPER SERIES

EMPIRICAL STUDIES OF INNOVATION IN THE KNOWLEDGE DRIVEN ECONOMY

\author{
Bronwyn H. Hall \\ Jacques Mairesse \\ Working Paper 12320 \\ http://www.nber.org/papers/w12320
}

\author{
NATIONAL BUREAU OF ECONOMIC RESEARCH \\ 1050 Massachusetts Avenue \\ Cambridge, MA 02138 \\ June 2006
}

The views expressed herein are those of the author(s) and do not necessarily reflect the views of the National Bureau of Economic Research.

(C2006 by Bronwyn H. Hall and Jacques Mairesse. All rights reserved. Short sections of text, not to exceed two paragraphs, may be quoted without explicit permission provided that full credit, including (C) notice, is given to the source. 
Empirical Studies of Innovation in the Knowledge Driven Economy

Bronwyn H. Hall and Jacques Mairesse

NBER Working Paper No. 12320

June 2006

JEL No. O3, M2

\section{$\underline{\text { ABSTRACT }}$}

This introduction to a special issue of EINT surveys a collection of ten papers that study various aspects of innovation and knowledge management and their impact on performance at the firm level for a number of countries. These studies have been conducted using data drawn from innovation surveys combined with data from a number of other sources. The issue illustrates the value of these surveys in improving our understanding of innovation in firms and raises a number of questions for future work in this area.

Bronwyn H. Hall

Department of Economics

549 Evans Hall, \#3880

University of California-Berkeley

Berkeley, CA 94720-3880

and NBER

bhhall@econ.berkeley.edu

Jacques Mairesse

INSEE, CREST

15, Boulevard Gabriel PERI

92245 MALAKOFF CEDEX

FRANCE

and NBER

mairesse@ensae.fr 


\title{
EMPIRICAL STUDIES OF INNOVATION \\ IN THE KNOWLEDGE DRIVEN ECONOMY \\ Introduction
}

\author{
Bronwyn H. Hall and Jacques Mairesse
}

During the past decade a number of countries in Europe and elsewhere have implemented enterprise-based surveys of innovative activity in an effort to broaden our collective understanding of the knowledge production and diffusion processes beyond what can be learned from the long-established analyses that mainly use R\&D expenditures and patent counts as indicators of the input and output of innovation. The ten studies collected in this special issue all make use of the data collected in such surveys, in many cases combined with a variety of other data sources, to give a richer picture of innovative activity at the firm level and of the ways in which knowledge is generated and transmitted within and between firms. ${ }^{3}$

These papers fall naturally into two groups. The first group presents five papers applying a model of the R\&D, innovation, and productivity interrelations at the firm level, more or less similar to that of Crepon, Duguet, and Mairesse (1998) paper (henceforth CDM) for France, to countries as different as Chile, Sweden, China and the Netherlands, and to a comparison of seven European countries. The second group

\footnotetext{
${ }^{3}$ This paper is the introduction to a special issue of Economics of Innovation and New Technology. Most of the papers in the volume were first presented at a conference organized by Almas Heshmati and Hans Lööf in Stockholm, Sweden, in January 2001, and have since been substantially revised. A Table of Contents for the volume is given at the end of the paper.
} 
consists of a number of studies that concern more directly various aspects of firm knowledge management. We discuss each of these two groups of papers in the next two sections of the introduction.

\section{ECONOMETRIC MODELS OF R\&D, INNOVATION AND PRODUCTIVITY}

In an influential article, Griliches (1979) laid out a framework for the analysis of innovation and productivity growth in the form of a flow chart that showed the path by which investment in research generated knowledge and the outputs and indicators of that knowledge. In Figure 1, we reproduce an elaboration of this figure from CDM, an elaboration that explicitly incorporates the elements used in the first group of papers in this special issue. The square boxes denote measurable quantities and the oval boxes unmeasured concepts for which we usually only have rather coarse proxies. Note the central roles played by the unobservable "knowledge" capital and innovation output in this graph. Various links in the structure exhibited by this figure have been studied by many researchers in the past.

The CDM paper accomplished three things with respect to understanding the channels linking investment in knowledge to productivity growth. The first was to pull together the important but largely separated lines of empirical research that had evolved since Griliches’ original conception into an encompassing model that had a structure similar to his original conception. The strands were studies of the determinants of R\&D investment, patent or innovation production functions, and production function estimation using R\&D (or occasionally innovation or patents) as an input. The second contribution was to make use of the new information provided by the European Community Innovation Surveys, in particular the share of sales of innovative products, 
as an alternative, possibly more appropriate, measure of innovation output than patents. These surveys also contained a number of potentially useful and interesting qualitative indicators on the innovation activities of firms such as the sources of innovation and whether the firm was more strongly influenced by technological changes or user demand.

The final contribution of the CDM paper was the development of an explicit modelling framework, in order to use appropriate estimation methods in the presence of sample selectivity (due to the firm's choice of whether or not to undertake R\&D), potential endogeneity of some of the right-hand side variables, and the partially qualitative nature of some of the dependent variables (binary or categorical). In performing these three tasks, the paper set up a relatively simple framework on which others could build, varying or improving the economic specification, data used, and econometric identification and estimation. The several papers in the first part of this volume have tried to do just this, in a number of different ways and to varying degrees.

The closest to the original CDM approach is that by Jose Miguel Benavente, who used data from Chile and obtained results that were somewhat different from CDM while using a model that is almost identical to the original. We will briefly outline the model used by Benavente, as it can serve as a basis for discussion of all the papers in the first group. There are three basic equations set up in a recursive manner, one that explains research investment ( $R \& D$ per worker), a second that explains innovation (proxied by innovative sales) using $\mathrm{R} \& \mathrm{D}$ intensity, and a third that translates innovation into productivity differences (measured as valued added per worker). In some of the other papers patents were available and are used instead of or in addition to innovative sales. 
Note that this recursive setup contains no feedback from productivity to innovative activities, although we might expect such a feedback to exist, either for Schumpeterian reasons or because of omitted variations in individual firm skills.

Econometrically there are three issues in estimating this kind of model: first, $R \& D$ is undertaken by only a subset of the firms, so consistent estimation requires using a generalized Tobit model that allows for correlation of the level of $R \& D$ with the decision to undertake R\&D. Second, innovation sales is measured as a share of sales, bounded between 0 and 1, so that it is convenient to model it with a logit transform to make it normally distributed. ${ }^{4}$ Finally, there are the usual endogeneity problems due to the presence of $R \& D$ and innovation sales on the right-hand side of some of the equations. As in CDM, the method of estimation in Benavente is asymptotic least squares (where the first and second moments of the data are treated as sufficient statistics for the underlying probability distribution), a consistent but not efficient estimator. As instruments for R\&D in the innovation sales equation, he uses the firm's market share and diversification; the instruments for innovation sales in the productivity equation are simply the determinants of $R \& D$. Demand pull and technology push indicators are controlled for in both $\mathrm{R} \& \mathrm{D}$ and innovation equations, and industry and size in all three equations.

Benavente finds that larger firms and firms with higher market shares in their industry have higher $R \& D$ intensities and that larger firms have a higher percentage of innovative sales. These findings are familiar from other countries, and confirm the

\footnotetext{
${ }^{4}$ In some cases the responses to this question are categories such as $<10 \%, 10 \%-25 \%$, and so forth. In these cases the appropriate model is an ordered probit model of some kind.
} 
Schumpeterian view of innovation as an activity undertaken by larger monopolistic firms. But contrary to the findings in several of the other papers, he also finds that R\&D did not contribute to innovative sales nor do innovative sales contribute to productivity for these Chilean firms (once size, capital per worker, industry and demand pull/technology push is controlled for). This may perhaps be a reflection of the very differing circumstances in a developing Latin American economy as compared to Western Europe. In particular it may be more important to specify the dynamic linkages between R\&D, innovation and productivity in a developing economy than a developed one, for which it is more likely that the cross-sectional estimates of a CDM type model can reflect long-run relations.

The paper by Gary Jefferson, Bai Huamao, Guan Xiaojing, and Yu Xiaoyun adds an equation for profitability as well as productivity to the model used by Benavente and estimates it on 20,000 large and medium-sized Chinese firms. As in the previous case, controls for size, industry, and the nature of ownership (private, foreign, or government) are included in all equations. Industry concentration (rather than the market share of the particular firm), lagged firm profitability, and lagged R\&D intensity are used as instruments for $\mathrm{R} \& \mathrm{D}$ intensity in the new product sales equation. There are no additional instruments for new product sales except for the firm’s age.

Unlike Benavente, Jefferson et al find that controlling for industry eliminates the relationship between $R \& D$ intensity and size or concentration. This may be because they have included lagged $R \& D$ intensity in their equation, which will tend to reduce the explanatory power of any other variables due to the widely observed persistence of R\&D (Hall, Griliches, and Hausman 1986). In the case of Chinese firms, R\&D intensity 
does influence new product sales, although it exhibits decreasing returns that are related to foreign ownership of the firms. In addition innovative sales is associated with greater productivity and profitability, especially in larger state-owned firms and local government collectives, suggesting that innovation can make a big difference in this sector, which is viewed as having an increasingly declining share of output. Jefferson et al go on to compute the total returns to $\mathrm{R} \& \mathrm{D}$, finding that they are 3 to 4 times that for ordinary investment in Chinese firms.

The paper by Hans Lööf and Almas Heshmati applies a version of the CDM model to Swedish data for the mid-1990s on both manufacturing and service firms. Because they matched the results of the CIS survey for Sweden to business register data, they are able to explore the sensitivity of their results to a number of different changes in specification and variables. In particular, they use a number of variables to measure the success of innovative output: value added per employee, sales per employee, profit before and after depreciation, all in logarithmic levels and growth rates, and the sales margin, in levels. An important difference between their paper and those described earlier is that their measure of innovation input is more comprehensive than $R \& D$ expenditure, as it includes spending on non-R\&D based innovation activities, the purchase of outside services, machinery, and equipment for innovation activities, industrial design expense related to producing new products, education directly related to innovation activities, and some marketing expense. They are also able to include a number of variables describing the human capital of the employees, the sources of knowledge available to the firm, their strategies toward cooperation with outside partners, and the innovation obstacles they face as instruments. 
The results of their analysis show that selection bias is less important for these Swedish data than it was for the original CDM study, but that simultaneity between innovation output and input produces a downward bias on the innovation coefficient in the productivity (sales or value added) equation. Like many previous researchers, they find that the likelihood of innovating rises with firm size and capital intensity in both manufacturing and services. However they find that after controlling for industry and obstacles to innovation investment, innovation intensity is not constant but falls significantly with size. The productivity of such investment in terms of innovative sales also suggests diminishing returns, with an elasticity of about one half. An interesting result is that for service firms, but not for manufacturing firms, the productivity of innovation investments is positively related to the interaction with scientific research via access to journals and professional conferences. Finally, for Swedish firms, both in manufacturing and in services, the elasticity of productivity with respect to the share of innovation sales is very similar to that previously obtained by CDM, around 0.1 . That is, when the share of innovative sales goes up ten per cent, value added increases one per cent, other things equal, while sales and profits show larger increases of about two per cent.

As in the base model of Lööf and Heshmati, the usual implementation of the CDM model measures the final output of innovation as value added per worker deflated by a broad economy level or industry level deflator, in essence assuming that innovation is cost-reducing rather than demand-shifting. ${ }^{5}$ George Van Leeuwen and Luuk Klomp

\footnotetext{
${ }^{5}$ This is not true in actual implementation, since value added is seldom deflated by a firm-specific deflator, implying that the demand-shifting effect of innovation is also included in the variable. Nevertheless, the usual interpretation of the coefficients of the standard model implicitly assumes no
} 
depart from this specification to estimate a model that explicitly incorporates the demand-shifting effects of innovative output by using revenue (sales) per worker as the productivity measure and including a term for process R\&D as well as innovative sales on the right-hand side. They apply this model to data on approximately 3000 Dutch firms drawn from the second CIS, and estimate it using methods that control for selectivity into the sample. They find that using revenue per worker as the productivity measure yields better results than value added per worker, and that the return to innovation investment is sensitive to the technological environment in which firms operate. They also find that the estimation method matters, with a complete structural model in the style of CDM being preferred.

The paper by Pierre Mohnen, Jacques Mairesse, and Marcel Dagenais illustrates the idea of an accounting framework for innovation, using micro-aggregated firm data for seven countries from the European Community Innovation surveys and measuring innovation intensity as the share of innovative sales due to improved or new products. They define "innovativity" as that part of innovation intensity which is not explained by a model that incorporates the usual predictive variables such as firm size, $R \& D$ intensity, and industry. That is, "innovativity" is the residual from an innovation production function, corresponding to the idea of productivity in standard production analysis. They find that they are more able to predict firm innovation propensity and intensity in the high-tech sectors than in the low tech-sectors, and that there are important differences in innovativity across countries, Italy and Germany appearing to be respectively the least and the most innovative countries. This paper represents an

market power for the firm on the demand side. See Klette and Griliches (1996), Griliches and Mairesse (1984, 1998) and Mairesse and Jaumandreu (2005) for further discussion of this model. 
initial foray into this kind of measurement and the concluding remarks of the paper make suggestions for further work.

\section{EMPIRICAL STUDIES OF KNOWLEDGE MANAGEMENT}

It is probably safe to say that empirical study of knowledge management at the firm level is still in its infancy, partly because of lack of the kind of detailed data or even measurement concepts to describe the object of study (Foray and Gault 2003). The studies in this special issue represent some preliminary investigations into the subject. They are based on a variety of surveys recently conducted in a number of countries (specifically Finland, Denmark, and France for the papers presented here) which have attempted to obtain information about the knowledge management practices and knowledge networking behaviour of individual manufacturing and service firms. For a study that explores the impact of these practices on productivity, see Kremp and Mairesse (2003).

The term knowledge management is used to refer to the practices, implicit or explicit, used by a firm to acquire new knowledge, and to rearrange and diffuse existing knowledge within the firm. It also includes strategies that are intended either to prevent the firm's own knowledge from "leaking” out or to encourage the diffusion of its knowledge to partner firms and others from whom the firm might benefit in reciprocal knowledge exchange. Although knowledge management is not identical to innovation, the two are often viewed as closely connected, in the sense that innovation can be viewed as the production of new knowledge, implying that firms which innovate will also be those that are more concerned with the management of the knowledge thus produced. This particular idea is strongly supported by a number of the correlations 
reported in this special issue, such as those between the use of knowledge management and the size, R\&D intensity, and sector of the firm.

Why is knowledge management of concern to economists and others who study innovation by business firms? Knowledge related to a firm's products and processes, both current and future, can be thought of as an asset, which therefore should be managed strategically to obtain the highest possible returns, as in the case of other assets of the firm such as its plant and equipment, or brand names. The traditional asset management questions are when, how much, and what to invest (in), when to stop investing in a particular asset, and when to divest or sell an asset off. To these traditional questions, knowledge management adds others that arise from the particular properties of knowledge: 1) the fact that it is often embedded in employees; 2) its partial public good nature; and 3) the frequent difficulty of buying it in the market. We discuss each of these ideas in turn.

Much of the knowledge created by a firm's activities is embedded to some extent in the human capital of its employees, who acquire it consciously as a part of their duties or unconsciously along with the other activities they perform. This fact has several implications for knowledge management: first, human resource management (HRM) practices will become quite important because current employees are not simply interchangeable with those outside the firm. Second, protecting firm rather than employee ownership of such knowledge may require active management of the transformation of tacit forms of knowledge (that in the heads of employees) to codified forms that can be transmitted to other employees (Cowan, David, and Foray 2000). Third, an important aspect of knowledge management within the firm is clearly the 
“absorptive capacity” identified by Cohen and Levinthal (1989) as the ability of the firm to acquire and make use of the results of others' R\&D activities; this ability is again strongly related to the human capital of a firm's employees.

These employee-related aspects of knowledge management are highlighted in two papers in this volume. Anker Lund Vinding's paper examines the role of the human capital of a firm's employees in determining absorptive capacity, using survey results from 1500 Danish firms in manufacturing and services in the mid-1990s. He confirms that firms with a greater share of share of highly educated employees are more likely to introduce products or processes new to the world (to innovate), and also that the use of modern human resource management (HRM) practices and the development of closer relationships with both vertically related firms and external knowledge institutions is positively related to innovation and negatively to imitation. Here innovation is defined as the introduction of products or processes new to Denmark or to the world, whereas imitation is an introduction that is merely new to the firm. The argument is that education, HRM practices, and external links are signs of higher absorptive capacity and that this in turn improves the firm's innovative performance. Although the links are tenuous, the results are suggestive.

Using a survey of French firms conducted by the Service des Etudes et Statistiques Industrielles (SESSI) in 1997, Francis Munier explores the use of codified procedures for a variety of knowledge creating and product development activities, finding that they are relatively more common in analyzing client relationships and product satisfaction, and relatively less common for the management of $R \& D$ and the acquisition of technical information, both external and internal. Codification is only 
very weakly related to the technological intensity of the firm's sector and somewhat more strongly related to firm size, suggesting that it becomes more important as employee functions become more specialized and interactions among them are more likely not to be face-to-face. Thus it does not appear from this survey evidence that technological orientation itself generates greater codification of procedures within the firm.

The public good nature of knowledge, which implies that it is both non-rival and nonexcludable (at least not easily excludable), means that knowledge managers must consider both the positive and negative aspects of diffusing the knowledge created by their firm. Benefits flow to the firm from monitoring the discoveries and new products of other firms, but at the same time, there are costs associated with too rapid diffusion of one's own discoveries, for example, due to competition from imitators. How firms manage this problem is the subject of Stéphane Lhuillery's paper in this volume, which uses the previously mentioned SESSI survey along with the French versions of the Community Innovation Surveys and R\&D data collected during the 1990s. Lhuillery correlates a number of qualitative measures of knowledge disclosure or leakage with firm characteristics, and finds that knowledge disclosure is more common among large, R\&D intensive firms in high technology sectors, and that it is correlated with patenting by the same firms, which may provide a modicum of protection from imitation arising from disclosure. He also finds that firm innovative performance is higher when the firm has a policy of permitting the diffusion of non-confidential technologies via publication or other means, controlling for R\&D intensity and sector. 
A final aspect of the conduct of $R \& D$ and innovative activity is that it is difficult to purchase needed inputs "off the shelf," or even to identify at the outset exactly which inputs will be needed. That is, many modern technologically complex products require a greater variety of inputs than can be produced by a single firm, even if it is large. This is especially true of "network" industries such as mobile telephony, where the products must work together in order to enhance consumer demand for them. The solution adopted by most firms in technologically intense sectors is to form R\&D alliances and joint ventures with firms that specialize in complementary technologies, but this in turn requires considerable knowledge management effort, both of the alliance itself and in order to minimize unwanted spillovers and acquire the necessary technological knowledge for production. Several papers in this volume (those by Munier, Leiponen, and Lhuillery) look at the relationship between alliance participation and knowledge management strategies.

Munier's evidence on this topic confirms the previous not very surprising findings in the literature that participation in $R \& D$ alliances is more likely if a firm is large or in a high technology sector. He then goes on to present evidence that codification of procedures associated with joint $R \& D$ activity is no more likely than for other activities, and in fact somewhat less likely than for the management of client relationships. This is perhaps somewhat unexpected given the prior discussion of the employee-specific nature of tacit knowledge, but may reflect the speed and uncertainty under which such alliances are conducted. When technology is rapidly changing and developing, it may not be productive to spend a great deal of time codifying what has been learned. In addition, Lhuillery presents evidence that firms participating in R\&D alliances are more 
likely to allow external knowledge disclosure by their engineers, implying generally more openness to the outside and perhaps a need to transfer tacit knowledge.

Aija Leiponen's paper focuses on a different aspect of knowledge management: how to structure contracts with customers when the product itself is knowledge. She uses a survey of approximately 200 Finnish business service (industrial design, advertising, engineering, management consulting, and $R \& D$ services) firms that was conducted in 2000 and argues that these firms need to align the control rights in their contracts with the nature of their knowledge base, which is characterized by their service and learning strategies. She finds that firms providing expert skills that are not R\&D-intensive and which report learning incrementally are less likely to retain the control rights to their output, whereas if they provide package solutions, or are more $R \& D$ and training intensive, they are more likely to retain control rights. She suggests that this is because control rights are less valuable when the knowledge being provided is tacit and nonreplicable (as in the case of expert services).

Most of the papers discussed in this section focus on a descriptive analysis of the relationship between various knowledge management techniques and firm characteristics. Lhuillery and Vinding also provide some preliminary indications on the relationship between knowledge management and innovative performance. On the other hand, Duguet's paper centers on a traditional measure of performance, total factor productivity, and examines the contribution of innovation and spillovers to this measure. He provides interesting evidence that innovative firms can be characterized as belonging to one of two different regimes: radical innovators rely strongly on firm-level spillovers, including the licensing of patents and formal internal research while 
incremental innovators rely mostly on the adoption of new equipment goods accompanied by their own informal research. Analyzing the two groups of firms separately, he finds that only radical innovators contribute significantly to TFP growth.

\section{CONCLUDING DISCUSSION}

This brief tour of the papers in our special issue has attempted to give some indication of the richness of the data and analysis to be found within them - the reader is encouraged to refer to the papers themselves for a much fuller discussion of their methods and results. Looking at the collection as a whole, however, several conclusions can be drawn. First, considerable progress has been made in modelling and the use of appropriate econometric estimation methods using the innovation survey data, following the path laid out by CDM. Second, it is clear that many of the most interesting results are obtained when researchers are able to combine the survey data with census-type information on the accounting data for the firms. Such matching enables the measurement of final outcomes in the form of profitability and productivity, rather than merely the intermediate step of product and process innovation. Third, many aspects of innovation and knowledge diffusion are not well captured by our conventional quantitative measures such as R\&D spending, patents, and productivity, and surveys such as the Community Innovation Surveys can contribute a great deal to our understanding of the innovative process.

In looking over the results and questions raised in these papers, we would have several recommendations for future work in this area. The first would be to draw the link between the Knowledge Management practices of the firms studied in the second group of papers with the CDM framework for the structural analysis of the path from $R \& D$ 
and innovation to firm productivity and profitability used in the first group. Some steps in this direction have been taken by Duguet, among others, but much more work can be done in this area. For example, to what extent does the use of good HRM practices or the nature of knowledge disclosure to others actually increase the innovative capacity of a firm, and to what extent are these factors simply signs of successful management in the same way that innovation is? That is, what are the feedback loops and what policy levers will be effective if we wish to increase innovative activity among firms? Much of what we have learned already from this collection of papers is suggestive of correlation, but causality is a more elusive goal.

To answer these kinds of questions it will be necessary to have survey data that can be matched to accounting data, and that is comparable across country and over time. ${ }^{6}$ In particular it would be desirable to construct panels of firms that have been resurveyed at different time periods. This would allow better control for the problems of unobserved heterogeneity such as "good management," although naturally it would bring with it the usual problem of exacerbated measurement error, perhaps increased to some extent due to the qualitative nature of some of the data. Nevertheless, this seems to us a useful goal to pursue.

In addition to data comparability across time and country, we would also argue that comparability in specification and method is an area where progress could be made.

\footnotetext{
${ }^{6}$ In this regard it might be helpful and informative if the largest innovative economy, the United States, had a survey that was comparable to the ones analyzed here. Although some private efforts exist (Levin et al 1987; Cohen et al 2000), there does not yet exist a broad-based government administered innovation survey in that country.
} 
There is an understandable (and even desirable) tendency for each group of researchers to "go its own way" in analyzing these data in order to focus on a specific question of interest to them. But this sometimes sacrifices our ability to learn from the comparisons across studies and countries. To choose an example from the papers collected here, does innovation really contribute little to Chilean productivity and a great deal to Chinese productivity or are the differences in results due to the considerable difference in the specification of the models used for the two countries? Or, what exactly are the differences between using $R \& D$ spending to measure innovative investments and using a broader measure? To answer these kinds of questions, a great deal of attention needs to be paid to the precise specification and estimation methods used to ensure that the same ones are applied to data from different countries. We hope that some future researchers will be inspired by these papers to explore more thoroughly the crosscountry comparison of the firm-level innovative process using a common framework, as is done in the Mohnen et al. paper. 


\section{References}

Cohen, W. M. and Levinthal, D. A. (1989) Innovation and Learning, The Two Faces of R\&D. Economic Journal, 99, 569-96.

Cohen, W. M., R. R. Nelson and J. P. Walsh (2000) "Protecting Their Intellectual Assets: Appropriability Conditions and Why Firms Patent or Not?,” National Bureau of Economic Research Working Paper No. 7552.

Cowan, R., P. A. David, and D. Foray (2000) The Explicit Economics of Knowledge Codification and Tacitness. Industrial and Corporate Change, 9 (2), 211-253.

Crepon, B., E. Duguet, and J. Mairesse (1998) Research, Innovation, and Productivity, An Econometric Analysis at the Firm Level. Economics of Innovation and New Technology, 7 (3), 115-156.

Foray, D., and F. Gault (2003) Measuring Knowledge Management. Paris: OECD.

Griliches, Z. (1979) Issues in Assessing the Contribution of R\&D to Productivity Growth. Bell Journal of Economics, 10, 92-116.

Griliches, Z. and J. Mairesse (1998) Production Functions: The Search for Identification. in Econometrics and Economic Theory in the $20^{\text {th }}$ Century, The Ragnar Frisch Centennial Symposium, S. Ström (ed.), Cambridge University Press, pp. 169203. Reprinted in Z. Griliches, Practising Econometrics, Essays in Method and Application, Edward Elgar, 1998, pp. 383-411.

Griliches, Z. and J. Mairesse (1984) Productivity and Research Development at the Firm Level” pp. 271-297, in Research and Development, Patents and Productivity, Griliches ed., Chicago University Press. Reprinted in Z. Griliches, $R \& D$ and Productivity, The Econometric Evidence, Chicago University Press, 1998, pp. 100-133. Hall, B. H., Z. Griliches and J. A. Hausman (1986) Patents and R\&D, Is There a Lag?. International Economic Review, 27, 265-283. 
Klette, T. J., and Z. Griliches (1996) The Inconsistency of Common Scale Estimators When Output Prices are Unobserved and Endogenous. Journal of Applied Econometrics, 11, 343-361.

Kremp, E., and J. Mairesse (2003) Knowledge Management, Innovation and Productivity, A Firm Level Exploration Based on French Manufacturing CIS3 Data. In D. Foray and F. Gault (eds.), Measuring Knowledge Management. Paris: OECD.

Levin, R. C., A. K. Klevorick, R. R. Nelson and S. G. Winter (1987) “Appropriating the Returns from Industrial Research and Development,” Brookings Papers on Economic Activity 3, 783-832.

Mairesse J. and Jaumandreu J. (2005) “Panel-data Estimates of the Production Function and the Revenue Function: What Difference Does it Make?” Scandinavian Journal of Economics 107(4): 651-672. 
Figure 1

\section{Innovation and Productivity}

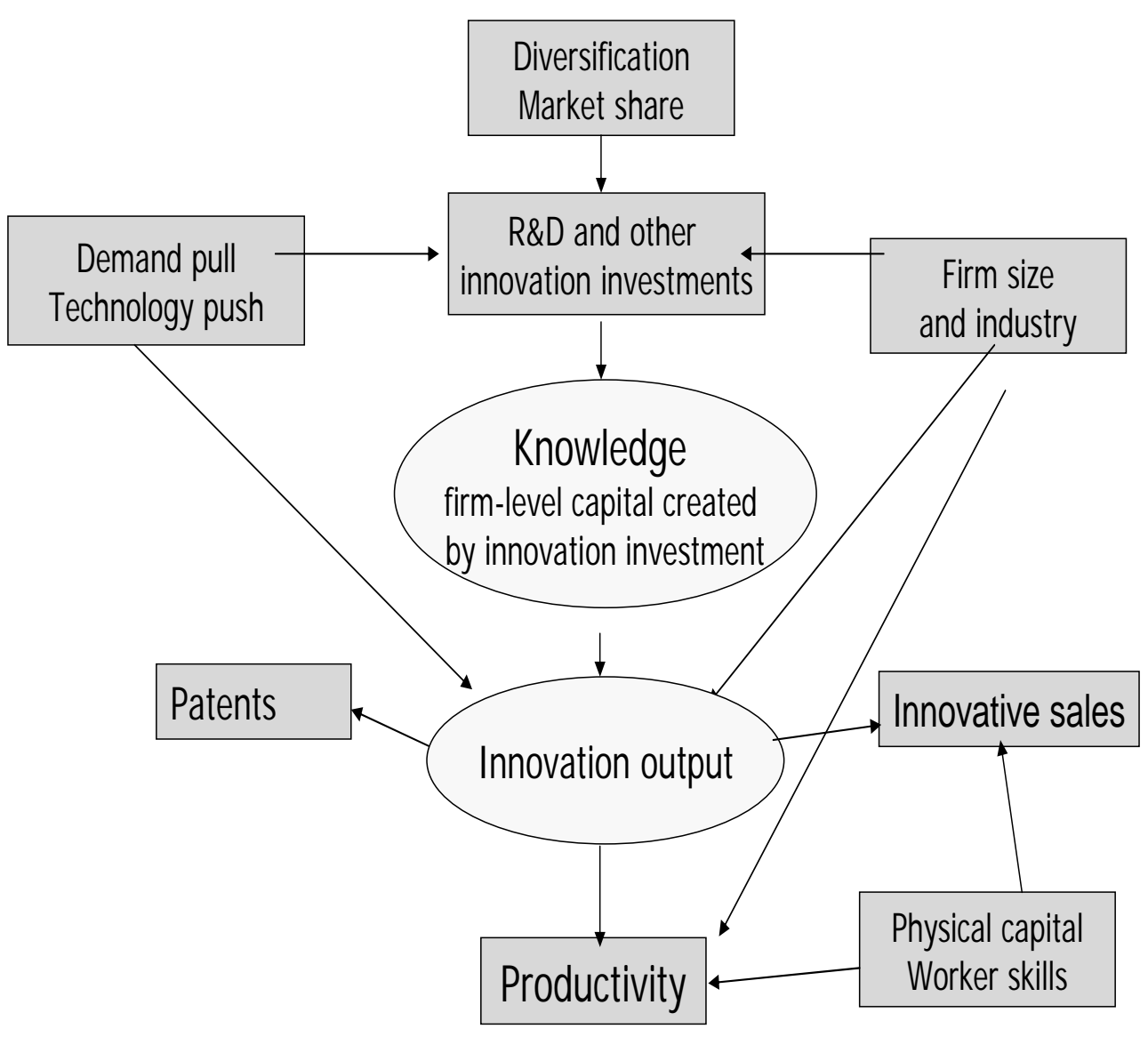


Table 1: Part I

\begin{tabular}{|c|c|c|c|c|c|c|c|}
\hline Authors & Title & Country & Years & Sample & Dep Var & Indep Var & Methodology \\
\hline Benavente & $\begin{array}{l}\text { The Role of Research and } \\
\text { Innovation in Promoting } \\
\text { Productivity in Chile }\end{array}$ & Chile & $1995-98$ & 488 Chilean plants & $\begin{array}{l}\text { R\&D intensity } \\
\text { Share innovative sales } \\
\text { Labor productivity }\end{array}$ & $\begin{array}{l}\text { size,mkt share, diversification } \\
\text { size, R\&D } \\
\text { size, innovation, capital intensity }\end{array}$ & $\begin{array}{l}\text { ALS with } \\
\text { selectivity and } \\
\text { simultaneity }\end{array}$ \\
\hline $\begin{array}{l}\text { Loof and } \\
\text { Heshmati }\end{array}$ & $\begin{array}{l}\text { On the Relationship between } \\
\text { Innovation and Performance: } \\
\text { A Sensitivity Analysis }\end{array}$ & Sweden & $1996-98$ & $\begin{array}{l}\text {-3000 service and } \\
\text { manufacturing firms; } \\
1300 \text { in innovation } \\
\text { sample }\end{array}$ & $\begin{array}{l}\text { R\&D intensity } \\
\text { Innovative sales per } \\
\text { worker } \\
\text { Labor productivity }\end{array}$ & $\begin{array}{l}\text { size, capital intensity, human } \\
\text { capital;competition; factors } \\
\text { hampering innovation } \\
\text { size, R\&D, capital intensity, mkt } \\
\text { growth; knowledge sources, Mills } \\
\text { ratio } \\
\text { size, innovation sales per worker, } \\
\text { capital intensity, human capital, } \\
\text { innovation type }\end{array}$ & $\begin{array}{l}\text { Generalized } \\
\text { Tobit } \\
\text { 3SLS }\end{array}$ \\
\hline $\begin{array}{l}\text { Jefferson, } \\
\text { Huamao, } \\
\text { Xiaojing, and } \\
\text { Xiaoyun }\end{array}$ & $\begin{array}{l}\text { R\&D Performance in Chinese } \\
\text { Industry }\end{array}$ & China & 1997-99 & $\begin{array}{l}20,000 \text { large } \& \text { medium- } \\
\text { sized manufacturing } \\
\text { firms; } \sim 5000 \text { in balanced } \\
\text { R\&D panel }\end{array}$ & $\begin{array}{l}\text { R\&D intensity } \\
\text { Share new product sales } \\
\text { TFP } \\
\text { profitability }\end{array}$ & $\begin{array}{l}\text { size, concentration, lag profits, } \\
\text { industry, ownership type, lag R\&D } \\
\text { intensity } \\
\text { R\&D intensity, R\&D-size interaction, } \\
\text { firm age, industry, ownership } \\
\text { size, innovative sales share, capital, } \\
\text { materials, industry, ownership } \\
\text { size, innovative sales share, capital, } \\
\text { industry, ownership }\end{array}$ & IV \\
\hline $\begin{array}{l}\text { van Leeuwen } \\
\text { and Klomp }\end{array}$ & $\begin{array}{l}\text { On the Contribution of } \\
\text { Innovation to Multi-factor } \\
\text { Productivity Growth }\end{array}$ & Netherlands & $1994-96$ & $\sim 3000$ firms & $\begin{array}{l}\text { Innovation intensity } \\
\text { R\&D intensity } \\
\text { Value added } \\
\text { Growth in VA }\end{array}$ & $\begin{array}{l}\text { size, market share, tech. push, } \\
\text { demand pull, science }\end{array}$ & $\begin{array}{l}\text { OLS, 3SLS } \\
\text { with and } \\
\text { without } \\
\text { selectivity }\end{array}$ \\
\hline $\begin{array}{l}\text { Mohnen, } \\
\text { Mairesse, } \\
\text { and Dagenais }\end{array}$ & $\begin{array}{l}\text { Innovativeness: A } \\
\text { Comparison across Seven } \\
\text { European Countries }\end{array}$ & $\begin{array}{c}\text { Seven } \\
\text { European } \\
\text { countries }\end{array}$ & 1992 & $\begin{array}{l}\text { CIS1 micro-aggregated } \\
\text { data. } \sim 8000 \text { firms; } \sim 5700 \\
\text { in innovation sample }\end{array}$ & $\begin{array}{l}\text { Being innovative } \\
\text { Innovation intensity }\end{array}$ & $\begin{array}{l}\text { size, industry, ownership type, } \\
\text { continuous R\&D,cooperative } R \& D \text {, } \\
\text { R\&D intensity, proximity to basic } \\
\text { research, perceived competition }\end{array}$ & $\begin{array}{l}\text { Generalized } \\
\text { Tobit }\end{array}$ \\
\hline
\end{tabular}


Table 1: Part II

\begin{tabular}{|c|c|c|c|c|c|c|c|}
\hline Authors & Title & Country & Years & Sample & Dep Var & Indep Var & Methodology \\
\hline Duguet & $\begin{array}{l}\text { Innovation height spillovers } \\
\text { and TFP growth at the firm } \\
\text { level: Evidence from French } \\
\text { Manufacturing }\end{array}$ & France & $1986-90$ & $\begin{array}{l}\sim 4000 \text { innovating } \\
\text { manufacturing firms from } \\
\mathrm{CIS} \mathrm{I}\end{array}$ & $\begin{array}{l}\text { Innovation height } \\
\text { (no/incremental/radical); } \\
\text { TFP growth }\end{array}$ & $\begin{array}{l}\text { sales, market share, diversification, } \\
\text { C4, tech push, demand pull, R\&D, } \\
\text { patents, external R\&D, type of } \\
\text { goods; } \\
\text { type of innovation, industry, lag TFP } \\
\text { inst = demand pull, tech push, ind. } \\
\text { Dummies, innovation inputs, R\&D }\end{array}$ & $\begin{array}{l}\text { two step } \\
\text { (IV)/GMM }\end{array}$ \\
\hline Leiponen & $\begin{array}{l}\text { Organization of Knowledge } \\
\text { Exchange: An Empirical } \\
\text { Study of Knowledge Intensive } \\
\text { Business Service } \\
\text { Relationships }\end{array}$ & Finland & 2000 & $\begin{array}{l}2000 \text { business service } \\
\text { firms; sample used = } 167\end{array}$ & $\begin{array}{l}\text { Control rights allocated to } \\
\text { customer } \\
(0-3 \text { or } 0-1)\end{array}$ & $\begin{array}{l}\text { size; labor productivity, age, group } \\
\text { firm; product is package, product is } \\
\text { expert, independent product; whether } \\
\text { IP possible, R\&D intensity, learning, } \\
\text { collaboration, training investments }\end{array}$ & $\begin{array}{l}\text { probit, } \\
\text { ordered probit }\end{array}$ \\
\hline L'Huillery & $\begin{array}{l}\text { Voluntary Technological } \\
\text { Disclosure as and Efficient } \\
\text { Knowledge Management } \\
\text { Device: An Empirical Study }\end{array}$ & France & $\begin{array}{l}1986-90 \\
1997\end{array}$ & $\begin{array}{l}\text { Manufacturing firms from } \\
\text { CIS I; PACE; Innovation } \\
\text { competency survey; } \\
\text { R\&D survey, CIS II for } \\
\text { non-innovating firms. } \\
\text { Sample }=\sim 3500 \text { firms } \\
\text { (1500 innovative) }\end{array}$ & $\begin{array}{l}D \text { (some tech transfer) } \\
D \text { (comm with other firms) } \\
D(\text { auth to comm with other } \\
\text { firms) } \\
D \text { (perm to comm with } \\
\text { other firms) } \\
D \text { (patents) }\end{array}$ & $\begin{array}{l}\text { size, } R \& D \text { intensity; French or } \\
\text { foreign group; } D(R \& D) \text {, industry; } \\
R \& D \text { collaboration variables }\end{array}$ & $\begin{array}{l}\text { Probit for } \\
\text { innovative } \\
\text { firms; } \\
\text { bivariate } \\
\text { probit for } \\
\text { comm \& } \\
\text { patents }\end{array}$ \\
\hline Munier & $\begin{array}{l}\text { Firm Size, Technological } \\
\text { Intensity of sector and } \\
\text { Relational Competencies to } \\
\text { Innovate: French Industrial } \\
\text { Innovating Firms }\end{array}$ & France & 1997 & $\begin{array}{l}3175 \text { manufacturing } \\
\text { firms from CIS II Survey }\end{array}$ & $\begin{array}{l}\text { Competencies: } \\
\text { Tech K spillovers (non- } \\
\text { mkt) } \\
\text { Consumer demand } \\
\text { R\&D coop/public } \\
\text { Financial competency } \\
\text { marketing competency }\end{array}$ & $\begin{array}{l}\text { size, tech intensity of sector; share of } \\
\text { tacit knowledge in a competency }\end{array}$ & f OLS; means \\
\hline Vinding & $\begin{array}{l}\text { Absorptive Capacity and } \\
\text { Innovative Performance: A } \\
\text { Human Capital Approach }\end{array}$ & Denmark & 1993-95 & $\begin{array}{l}1500 \text { firms from } \\
\text { manufacuring/services } \\
\text { survey of org. \& tech } \\
\text { change 1993-95 merged } \\
\text { to register data 1990-97 }\end{array}$ & $\begin{array}{l}\text { innovative capacity of firm } \\
(0-3)\end{array}$ & $\begin{array}{l}\text { education, avg work experience, } \\
\text { HRM practices, external relations } \\
\text { (suppliers, knowledge inst.), sector, } \\
\text { size, computerization, subsidiary }\end{array}$ & ordered probit \\
\hline
\end{tabular}




\title{
SPECIAL ISSUE FOR EINT
}

\author{
EMPIRICAL STUDIES OF INNOVATION
}

IN THE KNOWLEDGE DRIVEN ECONOMY

Guest editors: Bronwyn H. Hall and Jacques Mairesse

Table of Contents

Empirical studies of innovation in the knowledge driven economy: An introduction Bronwyn H. Hall (University of California at Berkeley, University of Maastricht, and NBER) and Jacques Mairesse (CREST-ENSAE, UNU-MERIT, and NBER)

PART 1- Econometric models of R\&D, Innovation and Productivity

The role of research and innovation in promoting productivity in Chile Jose Miguel Benavente (Universidad de Santiago, Chile)

Knowledge capital and heterogeneity in firm performance. A sensitivity analysis Hans Lööf and Almas Heshmati (Royal Institute of Technology and the United Nations University)

R\&D performance in Chinese industry

Gary H. Jefferson (Graduate School of International Economics and Finance, Brandeis University); Bai Huamao (Graduate School of International Economics and Finance, Brandeis University); Guan Xiaojing (Department of Population, Social, and Technology Statistics, National Bureau of Statistics, China) and Yu Xiaoyun (Department of Industrial and Transportation Statistics, National Bureau of Statistics, China)

On the contribution of innovation to multi-factor productivity George van Leeuven (CPB Netherlands' Bureau for Economic Policy) and Luuk Klomp (Ministry of Economic Affairs, The Netherlands)

Innovativity: A comparison across seven European countries

Jacques Mairesse (CREST-INSEE and NBER), Pierre Mohnen (MERIT, Maastricht University and CIRANO)) and Marcel Dagenais (Université de Montréal and CIRANO)

\section{PART II- EMPIRICAL STUDIES OF KNOWLEDGE TRANSMISSION WITHIN AND BETWEEN FIRMS}

Innovation height, spillovers and TFP growth at the firm level: Evidence from French manufacturing for company performance Emmanuel Duguet (Université de Bretagne Occidentale and Eurequa, Université de Paris 1) 
Organization of knowledge exchange: An empirical study of knowledge-intensive business service relationships

Aija Leiponen (Cornell University)

Voluntary technological disclosure as an efficient knowledge management device: An empirical study

Stéphane Lhuillery (Université Paris Nord)

Size of firms and relational competencies: Evidence from French industrial firms Francis Munier (BETA, UMR CNRS, Strasbourg, France)

Absorptive capacity and innovative performance: A human capital approach Anker Lund Vinding (Business auc, Aalborg, Denmark) 